\title{
Anatolia
}

\section{Wine tourist profiling in the Porto wine cellars: segmentation based on wine product involvement}

\author{
Vasco Santos , Paulo Ramos , Nuno Almeida , João Marôco \& Enrique Santos- \\ Pavón
}

To cite this article: Vasco Santos, Paulo Ramos, Nuno Almeida, João Marôco \& Enrique Santos-Pavón (2020): Wine tourist profiling in the Porto wine cellars: segmentation based on wine product involvement, Anatolia, DOI: 10.1080/13032917.2020.1802308

To link to this article: https://doi.org/10.1080/13032917.2020.1802308

册 Published online: 06 Aug 2020.

Submit your article to this journal ¿

Q View related articles ¿

View Crossmark data \lceil 


\title{
Wine tourist profiling in the Porto wine cellars: segmentation based on wine product involvement
}

\author{
Vasco Santos ${ }^{\mathrm{a}, \mathrm{b}, \mathrm{c}}$, Paulo Ramos ${ }^{\mathrm{d}, \mathrm{e}}$, Nuno Almeida, ${ }^{\mathrm{f}, \mathrm{g}}$, João Marôco ${ }^{\mathrm{h}}$ and Enrique Santos-Pavón \\ aUniversidad de Sevilla, Sevilla, Spain; ' \\ - Escola Superior de Biotecnologia, Porto, Portugal; dUniversidade Católica Portuguesa Escola Superior de \\ Biotecnologia, Porto, Portugal; ' $F$ Fernando Pessoa University, Porto, Portugal; ' Instituto Politecnico de Leiria Escola \\ Superior de Turismo e Tecnologia do Mar de Peniche, Peniche, Portugal; IInstituto Politécnico DE Leiria Centro de \\ Investigação Aplicada em Turismo, Peniche, Portugal; ${ }^{\text {H} H i g h e r ~ I n s t i t u t e ~ o f ~ A p p l i e d ~ P s y c h o l o g y ~ W i l l i a m ~ J a m e s ~}$ \\ Center for Research, Lisboa, Portugal; 'Department of Physical Geography and Regional Geographical Analysis, \\ Universidad de Sevilla, Sevilla, Spain
}

\begin{abstract}
This paper segments a sample of 918 Porto wine cellars visitors based on their wine product involvement. A segmentation methodology was applied to the wine product involvement of wine tourists. Three clusters were identified with high, medium and low wine product involvement levels. The relevant theoretical contribution of this study was to provide new evidence of segmentation based on product involvement studies in the wine tourism market field in an area were empirical studies still remain scarce. The findings offer managerial implications regarding the wine tourists' identification and how to better adapt the visits. This is also the first study demonstrating wine tourist profiling and segmentation specifically applied to involvement with the Porto wine product.
\end{abstract}

\section{ARTICLE HISTORY}

Received 24 November 2019 Accepted 24 July 2020

\section{KEYWORDS}

Tourist segmentation; wine cellars tourists; wine product involvement; cluster analysis

\section{Introduction}

Wine tourism have been studied in various international contexts such as Australia (Mitchell et al., 2012); Canada (Getz \& Brown, 2006); New Zealand (Alonso, 2009); Chile (Kunc, 2009); Spain (Gómez \& Molina, 2012); United States (Bruwer \& Johnson, 2010; Bruwer \& Thach, 2013) and Portugal (Brás et al., 2013), among others.

Alebaki and Iakovidou (2011) noted a need for more quantitative research in this area, particularly in Europe. Charters and Ali-Knight (2002), pointed out a lack of research in the nature of wine tourists and their motivations as well as their segmentation. Recent authors also corroborate the fact that segmentation studies in the wine market yet have not reached maturity (Bruwer et al., 2017; Cuomo et al., 2016; Getz \& Brown, 2006; Johnson et al., 2017; Lockshin \& Corsi, 2012).

Several authors have contributed to the research in consumer profiling and segmentation regarding the wine context and wine tourism industry. Most researches are based around one or several wine products (Charters \& Pettigrew, 2006; Domenic \& Arnie, 2013; Schiefer \& Fischer, 2008). Nevertheless, not much research has yet been conducted about the wine market, namely focusing on the Porto wine cellars. This research is based on a cluster analysis of Porto wine visitor's involvement.

Bruwer and Buller (2013) argue that analysing the wine product involvement is critical for a better understanding of the wine tourist's behaviours. Wine tourists should not be treated as a homogeneous group because there is no standard stereotype of what is a wine tourist (Charters \& 
Ali-Knight, 2002; Galloway et al., 2008; Yuan et al., 2008). An identification of the main characteristics, and differences among wine tourists still constitutes a marketing challenge (Pomarici et al., 2017) being the market segmentation as a valuable tool to boost market growth.

The main aim of this paper is to provide a better understanding of the role that different levels of involvement of the wine tourist segments can help in the understanding of the different profiles and their main characteristics associated with them.

\section{Literature review}

The world wine market encapsulates a complex world with a great variety of producers, product, brand and grapes varieties trying to capture the consumers attention and income (Johnson et al., 2017). In the wine market, there are several criteria to consider as a targeting basis. From Brunner and Siegrist (2011) perspective, there are nine major variables of segmentation in the wine market: (1) quality, (2) consumption, (3) risk reduction, (4) occasion, (5) cultural, (6) behavioural, (7) involvement, (8) geographical, and (9) lifestyles. Hristov and Kuhar (2014) considered 13 attributes of wines in their study targeted at young adult consumers: (1) wine price, (2) grape variety, (3) type of wine, (4) alcohol content, (5) label design, (6) barrel-aged wine, (7) brand, (8) sugar content, (9) wine closure, (10) wine age/vintage, (11) medals/awards, (12) bottle design, and (13) country of origin, but it was not clear that these attributes were the most influential in wine choice behaviour. Pomarici et al. (2017) used product attributes on the basis of psychographic characteristics such as involvement, subjective knowledge, innovativeness and loyalty proneness through the best-worst scaling and identified four segments: (1) experientials, (2) connoisseurs, (3) risk minimizers and, (4) price-sensitive. Cho et al. (2017) identified and characterized five specific constraints clusters to visit wine regions: (1) interest, (2) information \& knowledge, (3) money \& time, (4) accessibility, and (5) social, to select target markets based upon behavioural similarities and attitudes of consumers.

In general, lifestyle (Bruwer et al., 2002; Bruwer \& Li, 2007), behaviour (Barber et al., 2008a; Goodman, 2009), and involvement (Barber et al., 2008b; Charters \& Pettigrew, 2006; Dodd et al., 1996; Lockshin et al., 2001; Quester \& Smart, 1996) are the most common types of wine segmentation. Bruwer et al. (2002) found five segments in their segmentation process research using a winerelated lifestyle approach for the wine market segmentation, namely (1) enjoyment-oriented social wine drinkers, (2) fashion/image-oriented wine drinkers, (3) ritual-oriented conspicuous wine enthusiasts, (4) purposeful inconspicuous premium wine drinkers, and (5) basic wine drinkers. In addition to this, Bruwer and $\mathrm{Li}$ (2007) later adopted a similar approach to which they added two more segments: mature time-rich wine drinkers and young professional wine drinkers. In a more current and advanced perspective, three new bases have already emerged in recent years in segmentation: (1) biological segmentation (Pickering \& Hayes, 2017; Thibodeau et al., 2017), (2) sustainability segmentation (Pomarici et al., 2016; Schäufele \& Hamm, 2017), and (3) social media segmentation (Cuomo et al., 2016).

Each consumer has their own perceptions about wine and the producers as well, which contributes to the fact that most consumers are overloaded with the usual technical, wine-related communication, which is understood as not at all accessible (Ramos et al., 2011). According to Yuan et al. (2005), wine drinkers exhibit differences according to their needs and desires, and in fact not only an understanding of consumer behaviour, but also the most appropriate targeting for a certain group is a barrier for wine companies. Furthermore, Goodman et al. (2005) state that a wine company may have difficulty in understanding which attributes of the product influence the consumer's purchasing decision, as a consequence of the wide variety of wine products.

In an approach to a global segmentation of the wine industry, Goodman (2009) used 13 attributes of high influence on the wine choice and compared the similarities and differences between 12 countries. Alebaki and Iakovidou (2011) questioned if wine has or not the motive for visiting a wine region and how wine tourism could be related to a single type of tourist. 


\section{Wine tourist profile and segmentation}

"The wine tourist is a person with needs to relate to both wine and the location (wine region) where wine is produced" (Bruwer \& Alant, 2009, p. 3). In light of this, wine tourism development has been increasingly international, and the need to better understand the nature of the wine tourist has been a major theme in the literature (Brown \& Getz, 2005). There are several concepts and perspectives to define the concept of the wine tourist. However, Galloway et al. (2008) define the wine tourist according to his/her degree of interest and knowledge about wine. Wine tourists are mainly consumers of wine (Brown \& Getz, 2005). While for many other scholars (Alebaki \& Iakovidou, 2011; Getz \& Brown, 2006) the wine tourist is defined and segmented by psychographic and demographic criteria, such as: age; education level; gender; income; lifestyle; personality; attitudes, interests and values. Charters and Ali-Knight (2002) classified tourists into four segments: "wine lovers" (high interest), "wine interested" (interested), "wine novice" (limited interest), and "hangers on" (not interested), who are included in a group but do not have or show any interest in wine. Kelley et al. (2019) conclude that the nature of the relationship between members of visit groups influences motivation-based segmentation, and socio-demographic group interaction effects exist in wine tourism.

Nella and Christou's study (Nella \& Christou, 2014) confirm that it is meaningful to segment winery visitors on the basis of their involvement with wine, divided into three groups of low, medium, and high involvement levels. Pomarici et al. (2017) identified four segments, namely (1) experientials, (2) connoisseurs, (3) risk minimizers and (4) price-sensitive, with significant differences for both their preferences towards wine and psychographic characteristics. Johnson, Danner and Bastian (2018) developed a comparison of real-world examples about wine market segments focused on the Australian market. These authors suggest that there are three stable segments concentrated on the domestic wine market: (1) connoisseurs, (2) social wine drinkers, and (3) basic wine drinkers. A cluster analysis about wine-related lifestyle segmentation in the context of urban Indian consumers resulted in a three-cluster solution, namely: cautious social drinker, loner regular drinker and highly engaged drinker (Sharma et al., 2020). In another segmentation study of sustainable wine consumers from the US, UK, and Germany, were segmented into four categories: (1) apathetic consumers; (2) health-conscious diners; (3) holistic perfectionists; and (4) ethical advocates (Ghvanidze et al., 2019). Yabin and Li (2019) identified five distinct segments within China's online wine market, based on the wine-related lifestyle: (1) wine business consumption type; (2) wine enthusiast consumption type; (3) wine enjoyment consumption type; (4) wine fashion consumption type; and (5) wine novice consumption type. Another perspective, related to a constraint-based approach to wine tourism market segmentation, Cho et al. (2017) generated five homogenous subgroups: (1) highly constrained; (2) cost \& time conscious; (3) family togetherness; (4) unmotivated; and (5) minimally constrained. Consequently, some differences have been identified in preference and intentions to visit wine regions among all these clusters above.

\section{Wine product involvement based on segmentation}

Wine product involvement is stated as "a motivational state of mind of a person with wine or winerelated activity ... which reflects the extent of personal relevance of the wine-related decision to the individual in terms of one's basic values, goals and self-concept" (Bruwer \& Huang, 2012, p. 463). Several studies suggest that the level of involvement with wine affects wine tourism pursuits (Brown et al., 2007; Getz \& Carlsen, 2008) and consumer behaviour (Wilson \& Schamel, 2010).

Dodd et al. (1996) established that the more involved wine drinkers are, the more they consume, and the more they are willing to spend on a bottle of wine. To Bruwer and Alant (2009), the wine tourist is a kind of consumer that is characterized by the need to get involved with both the wine and the wine region where the wine is produced. Bruwer and Buller (2013) have used the level of involvement to segment wine consumers. Quester and Smart (1996) found that wine region, price, 
grape variety and wine style were the product attributes which were most relevant, both in the decision process of wine purchase, as well as in consumer involvement. Charters and Pettigrew (2006) emphasized the relationship confirmed between the evaluation of wine and product involvement, based on groups and individual personal in-depth interviews. For these authors it was clear that there is a higher likelihood of especially poorly involved wine drinkers to focus more on sensory attributes of product quality, such as taste and flavour. The highly engaged consumer's tend to value attributes more of cognitive nature, such as interest and complexity. The wine involvement category, namely "the emerging wine learner" as a new wine consumer, was already suggested by Barber et al. (2008b) were the emerging wine learner desires two goals: to gain more interest in the wine area and also to learn about wine in order to become a wine enthusiast.

Nella and Christou (2014) confirmed that it makes sense to segment winery visitors based on their involvement with wine. They considered three groups of low, medium and high involvement. Brown et al. (2007) used ego involvement with wine as a segmentation basis for the wine tourism market in 4 segments: (1) hedonic aficionados, (2) cautious enthusiasts, (3) fastidious epicureans, and (4) functional differentiators. Identically, Yuan et al. (2008) segmented wine festival visitors into three groups, namely the low, medium, and high involvement groups, using a personal involvement inventory scale version as the adopted methodological criterion. Recently, Gu et al. (2018) segmented Chinese wine tourists based on four segments: (1) low involvement wine tourists, (2) highly involved wine tourists, (3) interest-driven wine tourists, and (4) high-risk perception wine tourists.

\section{Methodology}

Regarding sample design, the data was collected from a target study population of international wine tourists with a minimum age of 18 that were visiting Porto wine cellars. The self-reported questionnaires were applied in five languages: English, Spanish, French, Portuguese and German. In order to achieve a considerable sample size, when there is more affluence and attraction of high visitation, data were collected in four Porto wine cellars (Graham's, Taylor's, Croft and RamosPinto) in three different weeks between late July and September 2018 (the high season). The choice of a self-administrated questionnaire (one-to-one site surveys) as the data collection method was due to its higher precision and higher response and completion rates, and the advantage of being more "user friendly" (Veal, 1992). Therefore, a total of 918 self-administrated questionnaires were conducted and considered valid for data analysis.

\section{Wine product involvement measure}

The wine involvement scale was developed by Brown et al. (2007) based on the consumer involvement profile scale of Laurent and Kapferer (1985). This scale was chosen due to its validity and reliability ranging from.90 to .79 in order to measure wine product involvement. This scale was therefore regarded as more suitable. Accordingly, the intention of this scale is to measure more product-related nuances (namely the involvement with wine), in order to test whether the consumer interest in wine would lead the wine tourist to travel to the wine region. A list of eight items is considered to measure wine product involvement on the basis that they best represent the product involvement of the wine tourists with Porto wine, such as: (1) I am knowledgeable about wine; (2) Much of my leisure time is devoted to wine-related activities; (3) I have invested a great deal in my interest in wine; (4) Porto wine represents a central life interest for me; (5) For me, the Porto wine tastings are a particularly pleasurable experience; (6) I wish to learn more about wine; (7) I have a strong interest in Porto wine; (8) My interest in Porto wine makes me want to visit the cellars. All items of the wine involvement scale were measured on a Likert scale format (adapted to 7 points: $1=$ strongly disagree and $7=$ strongly agree). Respondents rate their level of agreement or disagreement with each statement, and items were adapted for the wine tourism context, but with minor adaptations. 


\section{Results}

Cluster analysis was performed using SPSS Statistics procedures (Charry et al., 2016; Marôco, 2018a). The representativeness of the sample that conducted this study allowed the results to be more robust and reliable. A K-Means cluster analysis of the wine product involvement (WPI) indicators determined the existence of three separate clusters. Cluster 1 has low averages in three indicators ("Much of my leisure time is devoted to Porto wine-related activities" (2.60), "I have invested a great deal in my interest in Porto wine" (2.72) and "Porto wine represents a central life interest for me" (3.08)) that have a higher product involvement with Porto wine, an intermediate average in one indicator and high averages in the remaining four. Cluster 2, which represents $64.7 \%$, demonstrates strong indicators regarding WPI (Table 1). This cluster has the strongest involvement with wine products. Cluster 1 shares the same level of interest in wine cellars and in Porto wine, while lacking the same levels of knowledge or everyday involvement with the product. Cluster 3 presents the lowest means in all indicators. WPI2, WPI3 and WPI4, similarly to Cluster 1, have less involvement with Porto wine. The indicator "I am knowledgeable about Porto wine" presents a low 2.85 average as well (with a median of 3 and a standard deviation of 0.178 ). Cluster 3 ranks higher in the other four WPI, but still below in comparison to the other two clusters, suggesting that it is made of wine tourists with lower knowledge of Porto wine, but with an average interest in Porto wine and wine cellars. We applied a one-way ANOVA in order to understand if these clusters present significant differences, which was followed by the Scheffe post hoc tests. All eight indicators of WPI differ significantly among three clusters supported by homogeneity test of variances. The follow-up Scheffe post hoc test details those differences, by analysing each of the eight indicators and if there are significant differences in relation to the three clusters. All of them present significant differences, as $\mathrm{p}=0.000$.

\section{Cluster characterization regarding sex, age and nationality}

Cluster 1 has a medium involvement (MI), followed by Cluster 2 with a higher level of involvement (HI), and lastly Cluster 3 with a low involvement (LI), as shown in Table 2. Regarding gender, there is a strong balance between Clusters 1 and 3, and less with Cluster 2. But the three clusters present a similar structure, with near 50\% men and 50\% women. There is a significant difference between age in each cluster. Cluster 2 (highly involved) is the oldest subgroup of the sample, with 45.19 , and lastly Cluster 3 (low involved) with 36.50. These results suggest that global WPI means tend to rise as the sample is composed of older individuals. When dividing ages into groups ( 35 - younger, 36 to 50 - young adult, 51 to 65 - adult, and 66 or older), one can once again conclude that Cluster 2 has the highest percentages among the three oldest groups and the lowest percentage among the youngest group. Cluster 3 is in a symmetrical position, while Cluster 1 is in the middle position in all four age groups.

Table 5 characterizes the clusters regarding the country of origin. There is a difference between these clusters in the weight of the category "Other countries", which is around $35 \%$ in Cluster 1 and 2 , but reaches almost $63 \%$ in Cluster 3. The other main difference is the relevance of French tourists in these clusters. Cluster 2 is the one with the strongest percentages of tourists coming from Spain (12.7\%), from Germany (7.9\%) and from the United Kingdom (14.4\%), in what is a subgroup composed of a significantly high level of European citizens.

In Table 4, the results show a dominance of European wine tourists in all clusters, particularly French wine tourists. Therefore, these results may suggest that European citizens have more interest, more knowledge and more investment in wine products, mainly due to the fact that more tourists came from these countries. As we progress to the clusters with the strongest performance in WPI indicators, the presence of Europeans also increases significantly. 


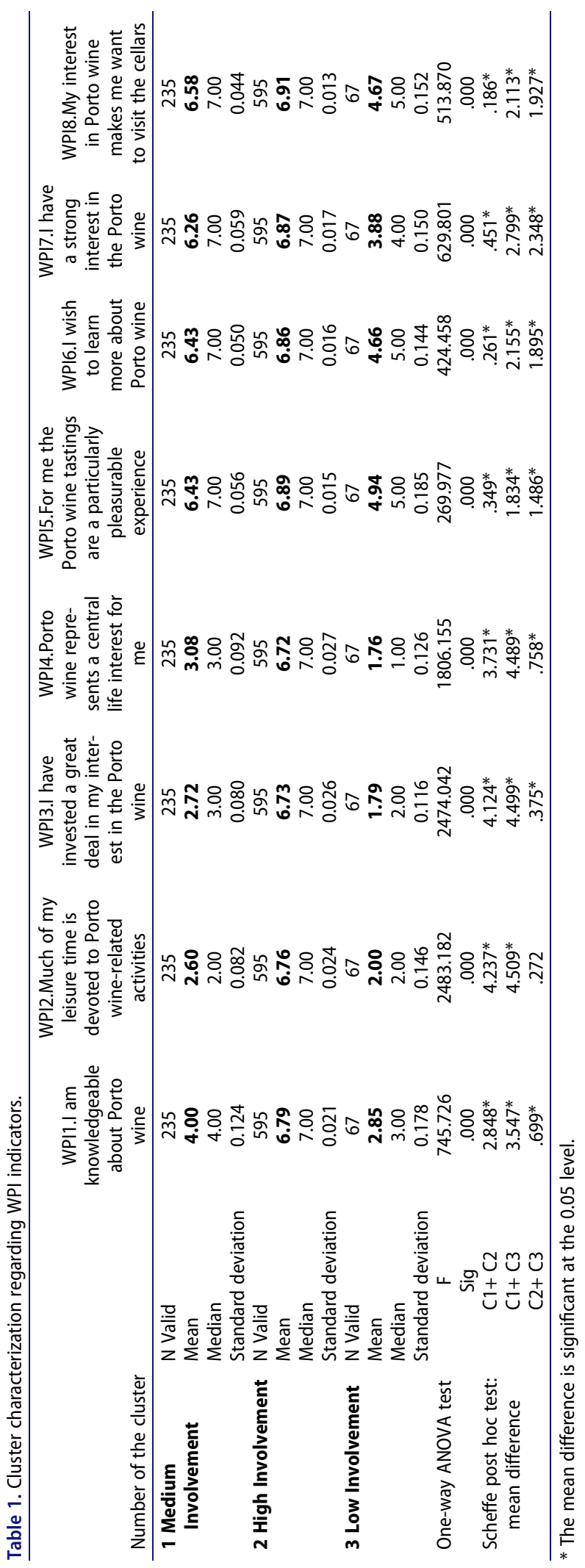


Table 2. Cluster characterization regarding gender and age of sample participants.

\begin{tabular}{|c|c|c|c|c|}
\hline \multicolumn{2}{|c|}{ Number of the cluster } & \multirow{2}{*}{$\frac{\text { Cluster } 1 \text { (MI) }}{233}$} & \multirow{2}{*}{$\frac{\text { Cluster } 2(\mathrm{HI})}{591}$} & \multirow{2}{*}{$\frac{\text { Cluster } 3 \text { (LI) }}{66}$} \\
\hline Age & Valid & & & \\
\hline & Omission & 2 & 4 & 1 \\
\hline & Mean & 40.65 & 45.19 & 36.50 \\
\hline & Median & 39.00 & 46.00 & 33.00 \\
\hline & Error deviation & 11.738 & 12.047 & 13.343 \\
\hline & Variance & 137.788 & 145.124 & 178.038 \\
\hline & ANOVA & \multicolumn{3}{|c|}{ ANOVA between age and cluster: Significance: $p=.000$} \\
\hline & to 35 - younger $-\mathrm{N}$ & 89 & 147 & 38 \\
\hline & 35 or younger $-\%$ & $38.2 \%$ & $24.9 \%$ & $57.6 \%$ \\
\hline & 36 to 50 - young adult $-\mathrm{N}$ & 92 & 244 & 18 \\
\hline & 36 to $50-\%$ & $39.5 \%$ & $41.3 \%$ & $27.3 \%$ \\
\hline & 36 to 50 - adult - N & 47 & 168 & 9 \\
\hline & 51 to $65-\%$ & $20.2 \%$ & $28.4 \%$ & $13.6 \%$ \\
\hline & 66 or more - older $-\mathrm{N}$ & 5 & 32 & 1 \\
\hline & 66 or $-\%$ & $2.1 \%$ & $5.4 \%$ & $1.5 \%$ \\
\hline \multirow[t]{6}{*}{ Gender } & Total - N & 234 & 592 & 66 \\
\hline & Total - Percentage & $100.0 \%$ & $100.0 \%$ & $100.0 \%$ \\
\hline & Female $-\mathrm{N}$ & 118 & 284 & 33 \\
\hline & Female - Percentage & $50.4 \%$ & $48.0 \%$ & $50.0 \%$ \\
\hline & Male - N & 116 & 308 & 33 \\
\hline & Male - Percentage & $49.6 \%$ & $52.0 \%$ & $50.0 \%$ \\
\hline
\end{tabular}

Table 3. Cluster characterization regarding nationality of sample participants.

\begin{tabular}{lccc}
\hline Cluster & Cluster 1 Percentage & Cluster 2 Percentage & Cluster 3 Percentage \\
\hline Valid & 100 & 100 & 100 \\
Missing & 0 & 0.1 & 0 \\
Portugal & 4.7 & 2 & 0 \\
Spain & 8.1 & 12.7 & 4.5 \\
France & 28.9 & 24.5 & 17.9 \\
Germany & 6.4 & 7.9 & 4.5 \\
United Kingdom & 8.9 & 14.4 & 9 \\
Brazil & 5.5 & 3.7 & 1.5 \\
Italy & 5.5 & 5.4 & 9 \\
Japan & 7.2 & 3.7 & 3 \\
Canada & 4.7 & 2.9 & 11.9 \\
Netherlands & 0.4 & 5.4 & 4.5 \\
USA & 3.8 & 3.5 & 6 \\
Other countries & 37.4 & 34.8 & 62.7 \\
\hline
\end{tabular}

Wine tourists' country of origin distribution per cluster was not homogenous; $x^{2}(12)=36.285 ; p<.001$ ).

Table 4. Cluster characterization regarding continent of origin of sample participants.

\begin{tabular}{|c|c|c|c|c|c|c|}
\hline $\begin{array}{l}\text { Number of } \\
\text { the cluster }\end{array}$ & $\begin{array}{l}\text { Cluster } 1 \\
\text { Frequency }\end{array}$ & $\begin{array}{c}\text { Cluster } 1 \\
\text { Percentage }\end{array}$ & $\begin{array}{l}\text { Cluster } 2 \\
\text { Frequency }\end{array}$ & $\begin{array}{c}\text { Cluster } 2 \\
\text { Percentage }\end{array}$ & $\begin{array}{l}\text { Cluster } 3 \\
\text { Frequency }\end{array}$ & $\begin{array}{c}\text { Cluster } 3 \\
\text { Percentage }\end{array}$ \\
\hline N Valid & 235 & 100.0 & 592 & 100.0 & 67 & 100.0 \\
\hline Omission & 0 & 0.0 & 3 & 0.1 & 0 & 0.0 \\
\hline Europe & 173 & 73.6 & 491 & 82.9 & 43 & 64.2 \\
\hline $\begin{array}{l}\text { North } \\
\text { America }\end{array}$ & 20 & 8.5 & 38 & 6.4 & 12 & 17.9 \\
\hline $\begin{array}{l}\text { South } \\
\text { America }\end{array}$ & 13 & 5.5 & 22 & 3.7 & 1 & 1.5 \\
\hline Asia & 22 & 9.4 & 33 & 5.6 & 6 & 9.0 \\
\hline Africa & 4 & 1.7 & 2 & 0.3 & 1 & 1.5 \\
\hline Australia & 3 & 1.3 & 6 & 1.0 & 4 & 6.0 \\
\hline
\end{tabular}

\section{Exploratory factor analysis}

An exploratory factor analysis (EFA) with a varimax rotation (Wedel \& Kamakura, 2000) was performed with all the wine product involvement items. A second EFA using the same criteria was made with the behavioural intention (BI) indicators. This analysis allowed an exploration of latent 
Table 5. Exploratory factor analysis of wine product involvement indicators and correlations with behavioural intentions.

\begin{tabular}{|c|c|c|c|c|}
\hline & \multicolumn{2}{|c|}{ Factor Matrix ${ }^{a}$} & \multicolumn{2}{|c|}{ Rotated Factor Matrix ${ }^{b}$} \\
\hline & 1 & 2 & $\begin{array}{l}1 \text { Prior acquired } \\
\text { knowledge }\end{array}$ & $\begin{array}{c}2 \text { Future learn- } \\
\text { ing/ } \\
\text { activities }\end{array}$ \\
\hline$\%$ of Variance & $65.41 \%$ & $18.86 \%$ & $44.49 \%$ & $39.77 \%$ \\
\hline WPI1.I am knowledgeable about Porto wine & .814 & -.377 & .857 & .266 \\
\hline $\begin{array}{l}\text { WPI2.Much of my leisure time is devoted to Porto wine-related } \\
\text { activities }\end{array}$ & .858 & -.436 & .929 & .252 \\
\hline WPI3.I have invested a great deal in my interest in Porto wine & .871 & -.433 & .936 & .262 \\
\hline WPI4.Porto wine represents a central life interest for me & .874 & -.380 & .903 & .304 \\
\hline $\begin{array}{l}\text { WPI5.For me the Porto wine tastings are a particularly } \\
\text { pleasurable experience }\end{array}$ & .697 & .419 & .237 & .778 \\
\hline WPI6.I wish to learn more about Porto wine & .775 & .485 & .250 & .879 \\
\hline WPI7.I have a strong interest in Porto wine & .811 & .411 & .326 & .849 \\
\hline WPI8.My interest in Porto wine makes me want to visit the cellars & .754 & .515 & .214 & .888 \\
\hline Correlations between factor and behavioural intentions & \multicolumn{2}{|c|}{ Group } & & \\
\hline \multirow[t]{4}{*}{ Behavioural Intentions } & & $.195^{* *}$ & $.549 * *$ \\
\hline & \multicolumn{2}{|c|}{$\begin{array}{l}\text { C1: Medium } \\
\text { Involvement }\end{array}$} & $-.323^{* *}$ & $.427 * *$ \\
\hline & \multicolumn{2}{|c|}{$\begin{array}{l}\text { C2: High } \\
\quad \text { Involvement }\end{array}$} & .030 & $.296 * *$ \\
\hline & \multicolumn{2}{|c|}{$\begin{array}{l}\text { C3: Low } \\
\text { Involvement }\end{array}$} & -.134 & .212 \\
\hline Structure Matrix of all Clusters & \multicolumn{2}{|c|}{$\begin{array}{c}\text { Function } 1 \\
\text { Prior } \\
\text { acquired } \\
\text { knowledge } \\
\end{array}$} & \multicolumn{2}{|c|}{$\begin{array}{c}\text { Function } 2 \\
\text { Future learning/activities }\end{array}$} \\
\hline WPI3.I have invested a great deal in my interest in Porto wine & \multicolumn{2}{|c|}{$.770 *$} & \multicolumn{2}{|c|}{-.324} \\
\hline $\begin{array}{l}\text { WPI2.Much of my leisure time is devoted to Porto wine-related } \\
\text { activities }\end{array}$ & \multicolumn{2}{|c|}{$.767^{*}$} & \multicolumn{2}{|c|}{-.437} \\
\hline WPI4.Porto wine represents a central life interest for me & \multicolumn{2}{|c|}{$.661 *$} & \multicolumn{2}{|c|}{-.144} \\
\hline WPI1.I am knowledgeable about Porto wine & \multicolumn{2}{|c|}{$.425 *$} & \multicolumn{2}{|c|}{-.060} \\
\hline WPI8.My interest in Porto wine makes me want to visit the cellars & \multicolumn{2}{|c|}{.275} & \multicolumn{2}{|c|}{$.786 *$} \\
\hline WPI7.I have a strong interest in Porto wine & \multicolumn{2}{|c|}{.325} & \multicolumn{2}{|c|}{$.768 *$} \\
\hline WPI6.I wish to learn more about Porto wine & \multicolumn{2}{|c|}{.264} & \multicolumn{2}{|c|}{$.647^{*}$} \\
\hline $\begin{array}{l}\text { WPI5.For me the Porto wine tastings are a particularly } \\
\text { pleasurable experience }\end{array}$ & \multicolumn{2}{|c|}{.220} & \multicolumn{2}{|c|}{$.461 *$} \\
\hline
\end{tabular}

Pooled within-groups correlations between discriminating variables and standardized canonical discriminant functions. Variables ordered by absolute size of correlation within function.

* Largest absolute correlation between each variable and any discriminant function.

factors defined by the WPI and BI sets of indicators. The values of the Kaiser-Meyer-Olkin (KMO) and Bartlett's test of sphericity (Hair et al., 2019; Johnson \& Bruwer, 2003; Bruwer \& Li, 2007) confirmed the sampling adequacy for performing factor analysis. The KMO presented high values for both groups of indicators ( 0.884 for WPI and 0.789 for BI), which confirmed that EFA is a suitable tool to explore the latent structure of the data. As for Bartlett's test of sphericity, both groups of indicators have a significance below 0.05 , once again indicating relevancy of the EFA. Table 5 presents the EFA results for wine product involvement (WPI). The EFA determined that BI is a single factor construct. Within the two WPI components, an analysis division into two separate factor suggests the existence of a first factor related to the prior knowledge about Porto wine acquired before the visit to the cellars, while the second factor is related to future learning/activities and is more related to a willingness to learn more in the visit.

The correlations between these two factors of the WPI and the BI allow us to explore and to find quite significant differences in relations between the three clusters and these factors. The correlation between behavioural intentions and prior acquired knowledge about port wine is weaker in general, but significant and negative with the medium involvement cluster and non-significant in the high and low involvement clusters. This gives evidence for these separate analyses. Regarding the relation 
between behavioural intention and future learning/activities, correlations are stronger, but still moderate and it is again in Cluster 1 that the strongest correlation is presented.

\section{Discriminant function analysis}

A discriminant function analysis was performed in order to build a predictive model of group membership, which shows statistically significant differences across the groups (Hair et al., 2019). The results of the discriminant function analysis contribute to an accurate quality performed for validation of the cluster analysis (Carvalho et al., 2015). Regarding the tests of equality of group means, all WPI variables demonstrate significant differences, with WPI2 and WPI3 presenting the greatest discriminatory power (Wilks' Lambda $=0.153$ ). The correlation matrix points out a strong relationship between WPI3 (I have invested a great deal in my interest in Porto wine) and WPI4 (Porto wine represents a central life interest for me), with 0.638. Regarding Box's test of equality of covariance matrices, the $\mathrm{p}$ value $(=<0.05)$ suggests there is non-equality of the matrixes of variance-covariance for the groups being studied. The Bartlett test shows the values are similar, therefore with no violation of homogeneity. The first function obtained through the canonical discriminant functions explain $92.6 \%$ of the variance of our dependent variable - the clusters with an eigenvalue of 9.214. Table 6 summarizes key data for the WPIs, helping to understand the relative importance of each of them in explaining the predicting variable. WPI2 and WPI3 emerge as the ones with the greatest importance.

The canonical discriminant function plot is a visual representation of the two functions generated from the structure matrix of the discriminant analysis. The previous table has the structure matrix for all clusters, identifying two functions. These two functions share the same divisions of indicators as in the rotated varimax factor matrix. Table 6 shows that the centroids from the three clusters groups (means of all variables in each cluster) are fairly detached among each other, suggesting that possible errors of classifications of cases into the clusters are less likely to happen. It is in the Function 1 axis that the differences between clusters are more prominent: Cluster 2 has the highest values, suggesting a stronger correlation to WPI indicators 5 to 8 . As for discriminant function 2, all cluster centroids are close to zero indicating that this function does not discriminate the clusters. Hence, this means that Function 1 is the one that best contributed to discrimination.

Globally, the empirical findings of this study confirm that it is a sound approach to distinguish different segments/clusters of different wine involvement levels for Porto wine cellars visitors. The results of this study shed light on the different importance and involvement that the Porto wine product has for wine tourists. The results are in line with those of Pomarici et al. (2017), who argued that consumers display different preferences towards wine. And it is common that through the criteria implemented in the various segmentation studies, the consumer profiles may differ considerably (Pomarici et al., 2017). Also, it is in keeping with Nella and Christou's study (Nella \& Christou, 2014) that suggested that it is meaningful to segment winery visitors on the basis of their involvement with wine, supporting that involvement with wine can provide a useful segmentation basis for the wine tourism market. Thus, the results of this study can help reduce the gap in the understanding how different wine involvement profiles may help explain the different types and levels of wine involvement. When the wine product involvement factor of "prior acquired knowledge" about Porto wine, although generally correlating with behavioural intentions, is broken down by cluster, the relationships between them are significantly different. This relationship with the medium involvement clusters is negatively correlated. That might suggest that the higher the involvement (which implies higher and previously acquired knowledge) the lower the behavioural intentions (recommending and returning). That suggest that this segment can consider that there is not much more to learn about Porto wine on a standard visit to a Porto wine cellar. Conversely the experience factor seems to motivate more future behavioural intentions. That implies that the experiential side of the visit, namely the tasting, is critical for enhancing future behaviours. This is reinforced by the fact that for those highly involved with Porto wine (Cluster 2), the acquired 
Table 6. Key data from canonical discriminant function and plot with canonical discriminant functions.

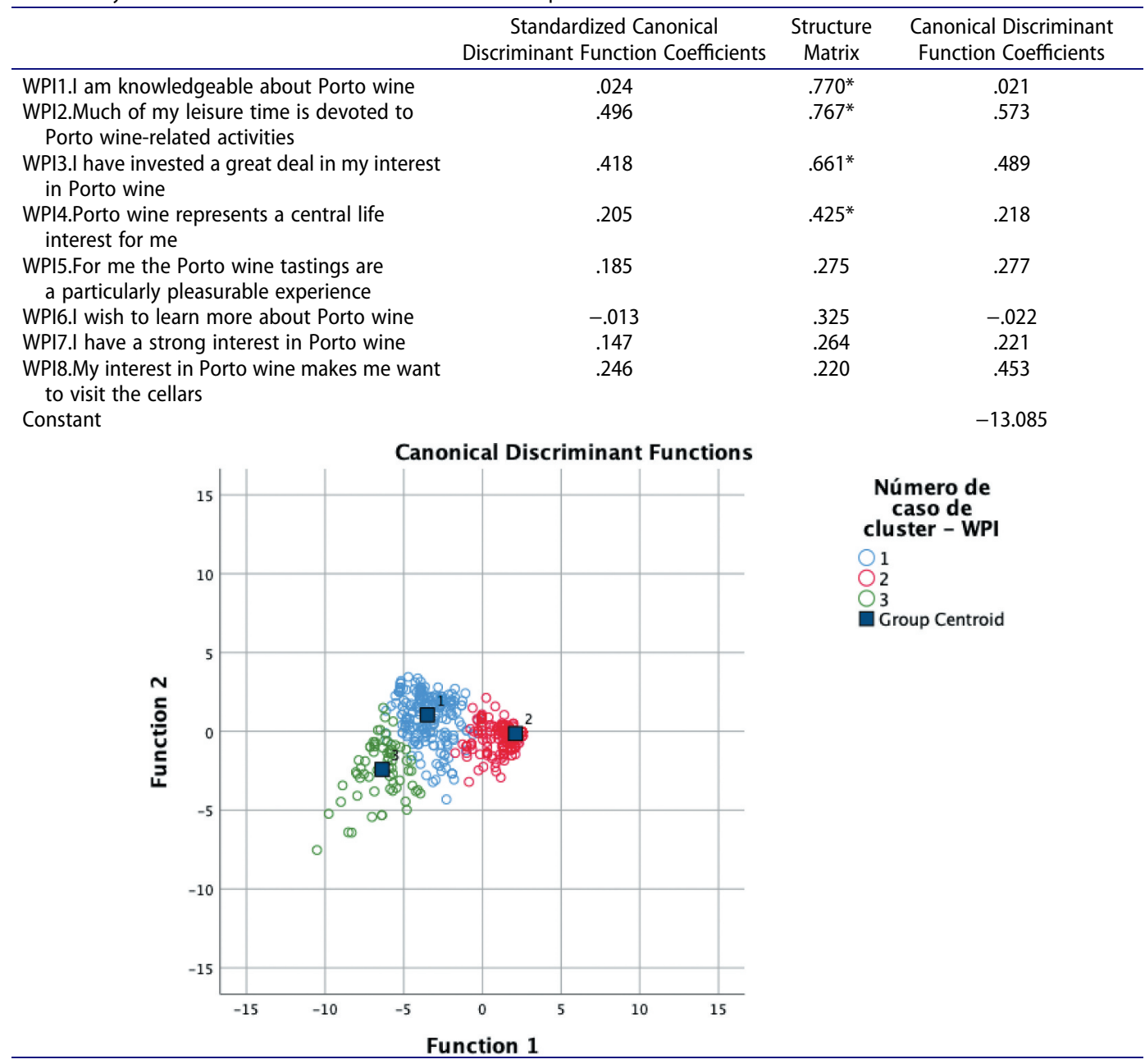

knowledge factor is not associated with future behavioural intentions. Nonetheless the learning activities seems to impact these behavioural intentions, although to a lesser extent than in Cluster 1 (medium involvement). As expected, in the low involvement Cluster (3) there is no significant relation with behavioural intentions.

\section{Conclusion and implications}

Market segmentation based on wine product involvement has been recognized as a valuable tool in profiling and segmentation consumers with similar needs and wants who are very likely to respond and behave in a similar way to marketing promotion and strategies from the wine and wine tourism business. Regarding the conclusions of the previous studies mentioned above in literature review, the findings of this research corroborate and reinforce the need for and high importance of recognition of the different wine involvement target markets. In this case the identification of different profiles of the wine tourists during their visits to the Porto Wine Cellars. This was done through the identification and characterization of different groups of wine tourists according to their wine involvement. 
The main goal of the study was to profile the wine tourists in the Porto wine cellars through segmentation based on wine product involvement. According to the results, three wine tourist clusters were identified in this study according to three clearly different levels of wine involvement: Those with a high wine product involvement (Cluster 2) with a medium wine product involvement (Cluster 1), and with low wine product involvement (Cluster 3). The chi-square test results showed the cluster differences in their behavioural characteristics with the Porto wine involvement. Cluster 1 comprises wine tourists with medium wine product involvement, representing $25.6 \%$ of the total sample. Cluster 2 includes wine tourists who were highly involved with Porto wine and accounted for $64.7 \%$ of the total sample. Cluster 3 shows the remaining respondents who are characterized by low wine product involvement with the lowest percentage (7.3\%). These results demonstrated the main different clusters based on wine product involvement attributes of the wine tourists that visited the Porto wine cellars. The major recommendation of this study, in terms of theoretical and managerial implications, consists of carrying out visits to the cellars on at least two levels. The first should be based on basic level and another for a higher level for connoisseurs. Therefore, it is suggested that the visits should be oriented according to the levels of involvement and knowledge that the visitors have regarding Porto wine. It is, therefore relevant that their level of interest should be assessed before the visit. This allows practical implications to be identified for wine and wine tourism marketing business and strategy management, namely the need to adapt the visits according to different levels of involvement that imply different levels of knowledge and expectations regarding the experiences provided by the visit.

The results provide direct implications for managers, tour guides and marketers to a successful targeting of the wine consumers in order to increase sales and positive word-of-mouth. The research has practical implications related to wine tourists' profile and segmentation to achieve a better competitive positioning of the visits and the wine activities and events.

Another targeting strategy for wine cellars could entail the use of the wine cellar experience during the visits as a tool to increase interest among wine tourists. This is particularly relevant for the low and medium involvement levels that could become more involved wine tourists. The wine cellar experience is, consequently, a great opportunity to create a stronger bond between the cellar and the wine tourist.

Ultimately, it is possible to uphold that involvement with wine can provide a very useful segmentation basis for the wine tourism market, and can also simultaneously be used as the basic input for newly designing their targeting, positioning and wine marketing mix strategies.

Regarding research limitations, the generalization of the results may be limited because the sample and data collection only occurred in a unique geographic and wine tourism point, Porto wine cellars. This study suggests directions for future research. The limitation regarding the identified reduced time period for data collection suggest a longitudinal evaluation of the wine product involvement of the wine tourists in wine tourism, not only in Porto wine cellars, but also in other types of wine products such as the Champagne, Madeira, Bordeaux wine and Mosel wine, among others.

\section{Disclosure statement}

No potential conflict of interest was reported by the authors.

\section{Notes on contributors}

Vasco Santos, $\mathrm{PhD}$ in Business Sciences with specialization in Marketing, MSc in Marketing and Tourism Promotion and BA in Hospitality Management. Coordinator Professor of Tourism and Marketing at ISLA Santarém. Coordinator of the Degree in Tourism Management. Researcher in CiTUR - Center for Tourism Research, Development and Innovation. Author of scientific papers and book chapters. Research areas: wine marketing, wine tourism, wine tourist behaviour, employer branding. 
Paulo Ramos, PhD Management Sciences University of Porto, MSc Marketing and Product Management, Cranfield University, UK, BA International Relations, Minho University. Assistant Professor at Fernando Pessoa University and Lusíada University. Former Marketing course coordinator in both universities. Guest lecturer in the Catholic University and FCUP. Researcher in CBQF. Member of the editorial board do Journal of Organizational Studies and Innovation, Management and Business Academy, UK. EU project expert and evaluator by appointment of the Northern Regional Coordination Commission (CCRN).

Nuno Almeida, $\mathrm{PhD}$ in Business Administration with specialization in Marketing and MSc in Economics and Industrial Strategy, both from the University of Coimbra. Professor in the Polytechnic of Leiria he's Coordinator of the Master Degree in Marketing and Tourism Promotion. Guest professor in different international universities he's research focus on Marketing, Entrepreneurship and Business Strategies. Coordination Member of the CiTUR Center for Tourism Research, Development and Innovation. Author of several scientific papers, chapters, and books he has an assortment of communications about new trends in Tourism Marketing.

João Marôco, Associate Professor of Statistics and Research Methods at ISPA-Instituto Universitário and a consultant on assessment and statistics of education for the World Bank. From 2014 to 2018 was a member of the Board of Directors of IAVE, I. P. (the Portuguese National Assessment Institute) and National Research Coordinator/National Program Manager for TIMSS, PIRLS, ICILS, and PISA. He has authored more than 300 peer-reviewed papers, 4 books and a dozen book chapters in statistics, psychometrics, biology, and the health sciences. According to Google Scholar, as of July 2020, his academic works have been quoted more than 27000 times $(H=55, \mathrm{I} 10=175)$. His main research interests are reading literacy prediction, student engagement and burnout, structural equation modeling and psychometric scale development.

Enrique Santos Pavón, is full Professor at University of Sevilla. He is part of the Physical Geography and Regional Geographical Analysis Department, with research interest in geography of tourism, tourism landscapes, tourism planning and typologies of tourist areas. He has published books and papers on rural tourism, urban tourism, coastal tourism, tourism planning and sustainable tourism topics.

\section{References}

Alebaki, M., \& Iakovidou, O. (2011). Market segmentation in wine tourism: A comparison of approaches. Tourismos: An International Multidisciplinary Journal of Tourism, 6(1), 123-140.

Alonso, A. D. (2009). Are travellers interested in wine tourism in New Zealand? International Journal of Culture, Tourism and Hospitality Research, 3(1), 13-24. https://doi.org/10.1108/17506180910940315

Barber, N., Dodd, T., \& Ghiselli, R. (2008a). Capturing the younger wine consumer. Journal of Wine Research, 19(2), 123-141. https://doi.org/10.1080/09571260802622225

Barber, N., Ismail, J., \& Dodd, T. (2008b). Purchase attributes of wine consumers with low involvement. Journal of Food Products Marketing, 14(1), 69-86. https://doi.org/10.1300/J038v14n01_05

Brás, J. M., Costa, C., \& Buhalis, D. (2013). Network analysis and wine routes: The case of the Bairrada Wine Route. The Service Industries Journal, 30(10), 1621-1641. https://doi.org/10.1080/02642060903580706

Brown, G., \& Getz, D. (2005). Linking wine preferences to the choice of wine tourism destinations. Journal of Travel Research, 43(3), 266-276. https://doi.org/10.1177/0047287504272027

Brown, G. P., Havitz, M. E., \& Getz, D. (2007). Relationship between wine involvement and wine-related travel. Journal of Travel \& Tourism Marketing, 21(1), 31-46. https://doi.org/10.1300/J073v21n01_03

Brunner, T., \& Siegrist, M. (2011). A consumer-oriented segmentation study in the Swiss wine market. British Food Journal, 113(3), 353-373. https://doi.org/10.1108/00070701111116437

Bruwer, J., \& Alant, K. (2009). The hedonic nature of wine tourism consumption: An experiential view. International Journal of Wine Business Research, 21(3), 235-257. https://doi.org/10.1108/17511060910985962

Bruwer, J., \& Buller, C. (2013). Product involvement, brand loyalty, and country-of-origin brand preferences of Japanese wine consumers. Journal of Wine Research, 24(1), 38-58. https://doi.org/10.1080/09571264.2012.717221

Bruwer, J., \& Huang, J. (2012). Wine product involvement and consumers' BYOB behaviour in the South Australian on-premise market. Asia Pacific Journal of Marketing and Logistics, 24(3), 461-481. https://doi.org/10.1108/ 13555851211237911

Bruwer, J., \& Johnson, R. (2010). Place-based marketing and regional branding strategy perspectives in the California wine industry. Journal of Consumer Marketing, 27(1), 5-16. https://doi.org/10.1108/07363761011012903

Bruwer, J., \& Li, E. (2007). Wine-related lifestyle (WRL) market segmentation: Demographic and behavioural factors. Journal of Wine Research, 18(1), 19-34. https://doi.org/10.1080/09571260701526865

Bruwer, J., Li, E., \& Reid, M. (2002). Segmentation of the Australian wine market using a wine-related lifestyle approach. Journal of Wine Research, 13(3), 217-242. https://doi.org/10.1080/0957126022000046510

Bruwer, J., Roediger, B., \& Herbst, F. (2017). Domain-specific market segmentation: A wine-related lifestyle (WRL) approach. Asia Pacific Journal of Marketing and Logistics, 29(1), 4-26. https://doi.org/10.1108/APJML-10-2015-0161 
Bruwer, J., \& Thach, L. (2013). Wine tourists' use of sources of information when visiting a USA wine region. Journal of Vacation Marketing, 19(3), 221-237. https://doi.org/10.1177/1356766712464768

Carvalho, N. B., Rodrigues-Minim, V. P., Nascimento, M., Teixeiria-Ribeiro-Vidigal, M. C., Marques-Ferreira, M. A., Arruda-Gonçalves, A. C., \& Minim, L. A. (2015). A discriminant function for validation of the cluster analysis and behavioral prediction of the coffee market. Food Research International, 77(3), 400-407. https://doi.org/10.1016/j. foodres.2015.10.013

Charry, K., Coussement, K., Demoulin, N., \& Heuvinck, N. (2016). Marketing research with IBM ${ }^{\circledR}$ SPSS statistics: A practical guide. Routledge.

Charters, S., \& Ali-Knight, J. (2002). Who is the wine tourist? Tourism Management, 23(3), 311-319. https://doi.org/ 10.1016/S0261-5177(01)00079-6

Charters, S., \& Pettigrew, S. (2006). Product involvement and the evaluation of wine quality. Qualitative Market Research: An International Journal, 9(2), 181-193. https://doi.org/10.1108/13522750610658810

Cho, M., Bonn, M. A., \& Brymer, R. A. (2017). A constraint-based approach to wine tourism market segmentation. Journal of Hospitality \& Tourism Research, 41(4), 415-444. https://doi.org/10.1177/1096348014538049

Cuomo, M. T., Tortora, D., Festa, G., Giordano, A., \& Metallo, G. (2016). Exploring consumer insights in wine marketing: An ethnographic research on \#winelovers. Psychology \& Marketing, 33(12), 1082-1090. https://doi.org/ 10.1002/mar.20942

Dodd, T. H., Pinkleton, B. E., \& Gustafson, A. W. (1996). External information sources of product enthusiasts: Differences between variety seekers, variety neutrals, and variety avoiders. Psychology \& Marketing, 13(3), 291-304. https://doi.org/10.1002/(SICI)1520-6793(199605)13:3<291::AID-MAR3>3.0.CO;2-7

Domenic, V. C., \& Arnie, F. C. (2013). As wine experts disagree, consumers' taste buds flourish: How two experts rate the 2004 Bordeaux vintage. Journal of Wine Research, 24(4), 311-317. https://doi.org/10.1080/09571264.2013. 837383

Galloway, G., Mitchell, R., Getz, D., Crouch, G., \& Ong, B. (2008). Sensation seeking and the prediction of attitudes and behaviors of wine tourists. Tourism Management, 29(5), 950-966. https://doi.org/10.1016/j.tourman.2007.11.006

Getz, D., \& Brown, G. (2006). Critical success factors for wine tourism regions: A demand analysis. Tourism Management, 27(1), 146-158. https://doi.org/10.1016/j.tourman.2004.08.002

Getz, D., \& Carlsen, J. (2008). Wine tourism among generations X and Y. Tourism, 56(3), 257-270. https://hrcak.srce. $\mathrm{hr} / 36617$

Ghvanidze, S., Velikova, N., Dodd, T. H., \& Oldewage-Theron, W. (2019). Are Sustainable consumers health conscious? A segmentation study of wine consumers. Journal of Food Products Marketing, 25(6), 690-711. https://doi.org/10.1080/10454446.2019.1640160

Gómez, M., \& Molina, A. (2012). Wine tourism in Spain: Denomination of origin effects on brand equity. International Journal of Tourism Research, 14(4), 353-368. https://doi.org/10.1002/jtr.868

Goodman, S. (2009). An international comparison of retail consumer wine choice. International Journal of Wine Business Research, 21(1), 41-49. https://doi.org/10.1108/17511060910948026

Goodman, S., Lockshin, L., \& Cohen, E. (2005). Best-worst scaling: A simple method to determine drinks and wine style preferences. The 2nd International Wine Marketing Symposium Proceedings, Sonoma State University, Sonoma, CA.

Gu, Q., Qiu Zhang, H., King, B., \& Huang, S. (2018). Wine tourism involvement: A segmentation of Chinese tourists. Journal of Travel \& Tourism Marketing, 35(5), 633-648. https://doi.org/10.1080/10548408.2017.1401031

Hair, J. F., Black, W. C., Babin, B. J., \& Anderson, R. E. (2019). Multivariate data analysis. Cengage.

Hristov, H., \& Kuhar, A. (2014). Young urban adult's preference for wine attributes applying best-worst scaling: An exploratory study for Republic of Macedonia. Bulgarian Journal of Agricultural Science, 20(3), 541-551.

Johnson, T., \& Bruwer, J. (2003). An empirical confirmation of wine-related lifestyle segments in the Australian wine market. International Journal of Wine Marketing, 15(1), 5-33. https://doi.org/10.1108/eb008749

Johnson, T., Danner, L., \& Bastian, S. E. P. (2017). Consumer segmentation methods for the wine market. In Reference module in food science (pp. 1-6). Elsevier.

Kelley, K. M., Bruwer, J., Zelinskie, J., Gardner, D. M., Govindasamy, R., Hyde, J., \& Rickard, B. J. (2019). Travel group member type effects in wine tourism: An ECHAID segmentation. Tourism Recreation Research, 44(1), 54-65. https://doi.org/10.1080/02508281.2018.1541578

Kunc, M. H. (2009). Forecasting the development of wine tourism: A case study in Chile. International Journal of Wine Business Research, 21(4), 325-338. https://doi.org/10.1108/17511060911004905

Laurent, G., \& Kapferer, J. N. (1985). Measuring consumer involvement profiles. Journal of Marketing Research, 22 (1), 41-53. https://doi.org/10.1177/002224378502200104

Lockshin, L., \& Corsi, A. M. (2012). Consumer behaviour for wine 2.0: A review since 2003 and future directions. Wine Economics and Policy, 1(1), 2-23. https://doi.org/10.1016/j.wep.2012.11.003

Lockshin, L., Quester, P. G., \& Spawton, T. (2001). Segmentation by involvement or nationality for global retailing: A cross-national comparative study of wine shopping behaviours. Journal of Wine Research, 12(3), 223-236. https:// doi.org/10.1080/09571260120106848

Marôco, J. (2018a). Análise Estatística com o SPSS statistics (7.a ed.). Pêro Pinheiro. 
Mitchell, R., Charters, S., \& Albrecht, J. N. (2012). Cultural systems and the wine tourism product. Annals of Tourism Research, 39(1), 311-335. https://doi.org/10.1016/j.annals.2011.05.002

Nella, A., \& Christou, E. (2014). Segmenting wine tourists on the basis of involvement with wine. Journal of Travel \& Tourism Marketing, 31(7), 783-798. https://doi.org/10.1080/10548408.2014.889639

Pickering, G. J., \& Hayes, J. E. (2017). Influence of biological, experiential and psychological factors in wine preference segmentation. Australian Journal of Grape and Wine Research, 23(2), 154-161. https://doi.org/10. 1111/ajgw.12266

Pomarici, E., Amato, M., \& Vecchio, R. (2016). Environmental friendly wines: A consumer segmentation study. Agriculture and Agricultural Science Procedia, 8, 534-541. https://doi.org/10.1016/j.aaspro.2016.02.067

Pomarici, E., Lerro, M., Chrysochou, P., Vecchio, R., \& Krystallis, A. (2017). One size does (obviously not) fit all: Using product attributes for wine market segmentation. Wine Economics and Policy, 6(2), 98-106. https://doi.org/ 10.1016/j.wep.2017.09.001

Quester, P. G., \& Smart, J. (1996). Product involvement in consumer wine purchases: Its demographic determinants and influence on choice attributes. International Journal of Wine Marketing, 8(3), 37-56. https://doi.org/10.1108/ eb008661

Ramos, P., Martins, F. V., \& Barandas, H. (2011). Differences in the perception on wine main attributes: A comparative view between consumers, producers and intermediaries. OIV Bulletin, 84(967), 271-306.

Schäufele, I., \& Hamm, U. (2017, March 7-10). Einstellungen und Präferenzen deutscher. In Technische Universität München (ed.), 14. Wissenschaftstagung Ökologischer Landbau (pp. 704-707). Freising-Weihenstephan, Dr. Köster.

Schiefer, J., \& Fischer, C. (2008). The gap between wine expert ratings and consumer preferences: Measures, determinants and marketing implications. International Journal of Wine Business Research, 20(4), 335-351. https://doi.org/10.1108/17511060810919443

Sharma, P., Singh, S., \& Misra, R. (2020). Wine-related lifestyle segmentation in the context of urban Indian consumers. International Journal of Wine Business Research, ahead-of-print No. ahead-of-print. https://doi.org/ 10.1108/IJWBR-05-2019-0036

Thibodeau, M., Bajec, M., \& Gary Pickering, G. (2017). Orosensory responsiveness and alcohol behaviour. Physiology \& Behavior, 177, 91-98. https://doi.org/10.1016/j.physbeh.2017.04.019

Veal, A. J. (1992). Research methods for leisure and tourism: A practical guide. Pitman.

Wedel, M., \& Kamakura, W. A. (2000). Market segmentation: Conceptual and methodological foundations (2nd ed.). Kluwer Academic Publishers.

Wilson, D., \& Schamel, G. (2010). Identifying the events that coincide with growth in wine involvement. In Proceedings of the 5th International Academy of Wine Business Research Conference (pp. 8-10/02). Auckland (New Zealand).

Yabin, W., \& Li, J. (2019). Segmentation of China's online wine market based on the wine-related lifestyle. British Food Journal, 122(8), 2385-2401. https://doi.org/10.1108/BFJ-04-2019-0295

Yuan, J., Morrison, A., Cai, L. A., Dodd, T., \& Linton, S. (2008). Segmenting wine festival visitors using their personal involvement with wine. In C. M. Hall \& L. Sharples (Eds.), Food and wine festivals and events around the world: Development, management and markets (pp. 146-165). Oxford: Butterworth-Heinemann.

Yuan, J., So, S., \& Chakravarty, S. (2005). To wine or not to wine: Profiling a wine enthusiast for a successful list. Journal of Nutrition in Recipe \& Menu Development, 3(3-4), 63-79. https://doi.org/10.1300/J071v03n03_06 